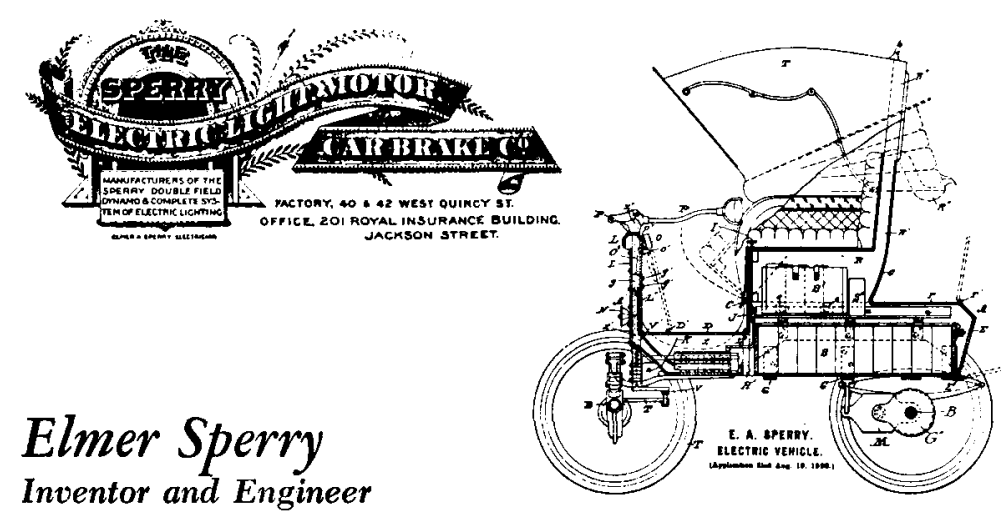

THOMAS P. HUGHES A major American inventor who obtained more than $35^{\circ}$ patents in his lifetime, Elmer Sperry contributed greatly to the momentous technological changes that occurred between 1880 and 1930 . In this first full-length biography, Professor Hughes treats Sperry as the prototype of the scientist-engineer deeply involved in private and government enterprise, and relates both him and his inventions to the society in which they flourished. "An important contribution both to the history of technology and to the writing of American biography." - Cyril Stanley Smith, Institute Professor, M.I.T.

"A remarkably good treatment of a highly technical subject. . . "- Robert P. Multhauf, Smithsonian Institution

Thomas P. Hughes is professor of the history of technology at Southern Methodist University. He has taught at Johns Hopkins, Harvard, M.I.T., and the University of Virginia.

$\$ 15.00$

\title{
The Emergence of Oligopoly
}

\section{Sugar Refining as a Case Study}

ALFRED S. EICHNER This historical account of the consolidation of the sugar refining industry is used as a case study to illustrate patterns of evolution in American business organization. Professor Eichner employs a unique fourstage model to demonstrate that the merger movement was motivated by the desire not to achieve economies of scale but to control prices.

$\$ 12.00$

\section{Peltries or Plantations}

The Economic Policies of the Dutch West India Company in New Netherlands, 1623-1639

VAN CLEAF BACHMAN Short-run exploitation or long-range development? These alternatives faced the Dutch West India Company when it chose between fur trading and colonization in New Netherlands. Dr. Bachman's study is the first systematic effort to examine the Dutch West India Company's economic policy in the light of its organizational structure and investment alternatives.

$\$ 7.50$

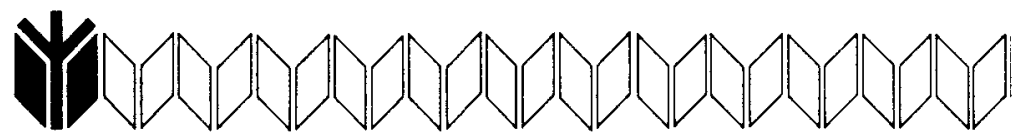

\section{THE JOHNS HOPKINS PRESS Baltimore, Maryland 21218}

Publishers of The Papers of Dwight David Eisenhower 


\section{REPRINTS AVAILABLE}

Business History Review

Volumes 1-40 and General Index, Volumes 1-27. Boston, Mass., 1926-1966. Available as follows: clothbound complete, $\$ 533.00$; paperbound complete, $\$ 475.00$; per volume or unit paperbound, $\$ 18.00$ (Volumes 1-24 reprinted in units of two or three volumes as follows: $1-3 ; 4-6 ; 7-9$; $10-12 ; 13-15 ; 16-18 ; 19-20 ; 21-22 ; 23-24$. Volumes 25-40 available separately.); General Index, Volumes 1-27, paperbound, $\$ 5.00$.

\section{Journal of Economic and Business History}

Volumes 1-4 (all published). Cambridge, Mass., 19281932. Available as follows: clothbound complete, $\$ 102.00$; paperbound complete, $\$ 90.00$; per volume, paperbound, $\$ 22.50$.

Order from:

\section{KRAUS REPRINT CO.}

A U.S. Division of Kraus-Thomson Organization Limited 16 East 46th Street

New York, New York 10017 


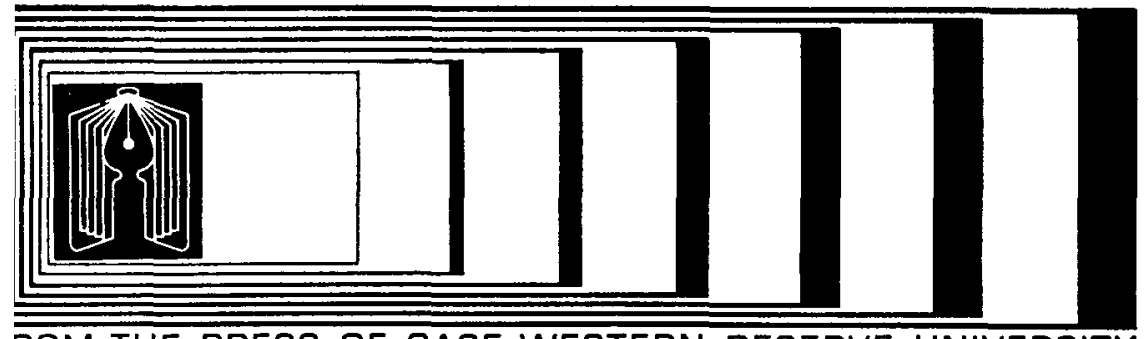

ROM THE PRESS OF CASE WESTERN RESERVE UNIVERSITY

\section{THE SOCIAL RESPONSIBILITIES OF BUSINESS}

\section{COMPANY AND COMMUNITY, 1900-1960}

\section{By Morrell Heald}

The concept of the social responsibility of business has roots reaching as far back in American history as the Puritan doctrine of stewardship and the nineteenth-century "Gospel of Wealth," and in this century business leadership has come fully to accept the involvement of the welfare of industry with the welfare of the community at large. In his history of the developing idea of corporate social responsibility, Dr. Heald traces the expansion of business programs for community betterment from support of the early Railroad YMCAs and the Community Chest movement in the twenties and thirties, to the emergence, since World War II, of substantial corporate subsidies for higher education and the fine arts. His study shows that external pressures from labor unions, government, churches, and educational institutions have contributed strongly to the rise of the corporate social conscience and that internal changes in the structure of modern enterprise have made business leaders highly aware of the social implications of their commercial policies.

Dr. Heald is professor of history and American studies at Case Western Reserve University. 


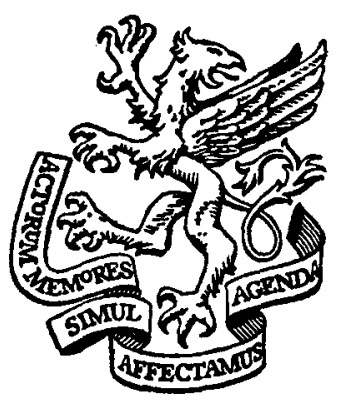

\title{
The Thomas Newcomen $\$ 1,000$ Award in Business History
}

\author{
Presented by \\ THE NEWCOMEN SOCIETY IN \\ NORTH AMERICA
}

\author{
in cooperation with
}

\section{THE BUSINESS HISTORY REVIEW}

C The Newcomen Society in North America, in cooperation with the Business History Review, announces a prize of $\$ 1,000$ and scroll to be awarded in 1973 for the best book on the history of business published in the United States during the years 1970-1972.

I For the purposes of this award, "the history of business" will be interpreted in its broadest sense, including not only the history of firms or industries, but books tracing interactions of businessmen, analyses of business philosophy or behavior, and studies of the adjustment of businesses and businessmen to their economic, political, and social environments.

a Criteria for selection will include contribution to knowledge, depth of analysis, soundness of reasoning, clarity of style and organization, and general readability and format.

a The committee to select the recipient of the 1973 Thomas Newcomen $\$ 1,000$ Award in Business History is composed of: Professor James P. Baughman, Editor, Business History Review, Harvard Graduate School of Business Administration; Mr. Stanley van den Heuvel, Trustee, The Newcomen Society in North America; and Professor Arthur M. Johnson, University of Maine, chairman.

c The 1973 Thomas Newcomen $\$ 1,000$ Award in Business History will be the fourth in a series of triennial prizes intended to encourage the study and improve the writing of business history in the United States and Canada. 


\title{
ECONOMY, SOCIETY, AND GOVERNMENT IN MEDIEVAL ITALY
}

\author{
Essays in Memory of Robert I. Reynolds
}

edited by DAVID HERLIHY, ROBERT S. LOPEZ, and VSEVOLOD SLESSAREV. A collection of essays in economic history focussed on the commercial life of pre-Renaissance Italy. Applying the quantitative tools of the social sciences to the business and financial records of the age, these investigations shed new light on the life and institutions of medieval Europe. / \$7.50

\section{FRESHWATER WHALES}

\section{A History of the American Shipbuilding Company and its Predecessors}

by RICHARD J. WRIGHT. The history of shipbuilding on the Great Lakes, a major industry since the early 19th century, is synonymous with the history of the American Shipbuilding Company, since this corporate giant now encompasses most of the earlier shipyards. Illustrated / $\$ 9.00$

\section{The Kent State University Press Kent, Ohio 44240}

The Legitimacy of the Business Corporation in the Law of the United States, $1780-1970$

By James Willard HuRst, University of Wisconsin

xiii, $19 I$ pp. bibliog., index.

This study deals with public policy and the business corporation in the United States from 1780 into the $1960^{\circ}$ s. The almost two hundred years of public policy which has concentrated in making the corporation a "legitimate instrument of business energy and ambition" is examined in detail. Mr. Hurst's inquiry into the legitimacy of privately organized power is the most complete study of this important force available.

\section{The Great Richmond Terminal}

By MaURY KLeIN, University of Rhode Island

xiii, 323 pp., maps, tables, apps., bibliog., index.

$\$ 9.5^{\circ}$

This case history of the Richmond Terminal, one of America's first pure holding companies, documents the process of economic development in the South during the postCivil War era.

\section{British Investment in American Railways, 1 $_{34-1898}$}

By Dorothy R. Adler. Edited by Muriel E. Hidy

262 pp. (tnt.) tables, apps., bibliog., index.

(Eleutherian Mills-Hagley Foundation)

This is the first attempt to describe in detail, from the British point of view, the character, size, and techniques of British investment in the railroads of the United States during the nineteenth century.

\section{University Press of Virginia}




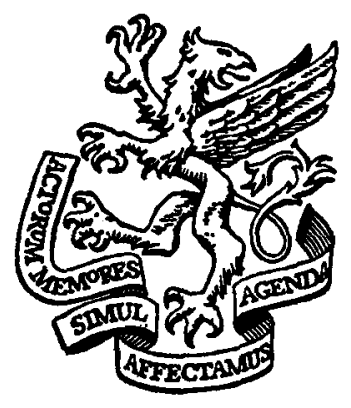

\title{
Newcomen Awards in Business History
}

\section{Presented by \\ THE NEWCOMEN SOCIETY IN NORTH AMERICA}

\author{
in cooperation with
}

\section{THE BUSINESS HISTORY REVIEW}

\begin{abstract}
a Two Newcomen Awards in Business History are offered annually for articles published in the Business History Review. The First Prize, of $\$ 250$, is awarded the article judged, according to the rules outlined below, to be the best of the year. The Special Award, of $\$ 100$, is for the best article by an author who is not more than 35 years of age and who has not published a book.
\end{abstract}

a Prize articles are selected by a panel of judges composed of a representative of The Newcomen Society and members of the Advisory Board of the Business History Review. No member of the Advisory Board or editorial staff shall be eligible for a prize, and articles so authorized will not be considered in the judging. Authors eligible for the Special Award shall also be eligible for the First Prize, but in no event shall both prizes be awarded for the same article. The Advisory Board reserves the right to withhold the Specinl Award in the event that eligible articles do not, in the Board's judgment, merit prize consideration. The awards program is administered by the editorial offices of the magazine.

a Criteria for selection include: originality, value, breadth, and interest of contribution, quality of research materials and methods, and quality of presentation. 


\section{EXPLORATIONS IN ECONOMIC HISTORY}

(formerly EXPLORATIONS IN ENTREPRENEURIAL HISTORY / SERIES 2)

A quarterly devoted to the application of the quantitative tools and theories of the economist to the study of man's social and political institutions and experiences. The topics range through business, financial, agricultural, manufacturing, and transportation systems, and the periods from the earliest historical records to the present day and from the industrial West to the developing areas of the East.

Annual subscription, $\$ 7.50$ domestic and Pan-American, $\$ 8.00$ elsewhere; single copy $\$ 2.00$.

Editor: Prof. Morton Rothstein, Graduate Program in Economic History, University of Wisconsin, Madison, Wisconsin 53706.

Published by The Kent State University Press, Kent, Ohio 44240.

\section{THE FREDERICK JACKSON TURNER AWARD}

$$
\text { of the }
$$

\section{ORGANIZATION OF AMERICAN HISTORIANS}

This yearly prize for the best monograph in American history, submitted by an author who has not previously published in book form. originated in 1958 as the MVHA Prize Studies Award.

PRIZE: $\$ 1500$ cash award plus publication as award winner and usual royalties from University of Kentucky Press

PUBLICATION: Manuscripts retained in the competition are assured of publication by the University of Kentucky Press

DECISION: Decision on publication is reached within six weeks

TIMETABLE: Awards are announced in April. Manuscripts received by December 1 are considered for the next year's award

Send inquiries to:

Executive Secretary, Organization of American Historians University of Utah

Salt Lake City, Utah 84112

You are invited to join the OAH. Send applications to the Secretary. 


\section{from Cambridge}

\section{THE ROYAL EXCHANGE ASSURANCE}

BarRy Supple

Founded in 1720, amid the frantic speculation associated with the South Sea Bubble, the Royal Exchange Assurance rapidly established itself as one of a handful of settled and powerful "monied companies". Being engaged in marine, fire, and life insurance, it benefited from the economic growth and social change which the Industrial Revolution brought to Britain.

This study analyzes the evolution of the Royal Exchange Assurance over 250 years and relates the growth of this firm to the development of British insurance as a whole.

$\$ 16.00$

\section{THE RETURN TO GOLD 1925}

\section{The Formulation of Economic Policy and its Critics}

D. E. MOGGRIDGE

The recent revision of the Official Secrets Act has released data that makes possible a completely new assessment of the most notorious British economic policy decision of the twentieth century - the return, in 1925, to the gold standard at the pre-war parity of $\$ 4.86$ to the pound.

Professor Moggridge discusses the background of the decision and the expectations of those who made and executed the policy.

Cloth $\$ 4.5^{\circ}$ Paper $\$ 2.75$

\section{THE HANDLOOM WEAVERS}

A Study in the English Cotton Industry during the Industrial Revolution

Duncan Bythell

“. . . an excellent example of what economic history should be."

\section{CAMBRIDGE UNIVERSITY PRESS}

32 East 57 th Street

New York, N.Y. 10022 


\title{
from Cambridge
}

\section{EUROPE IN THE RUSSIAN MIRROR}

Alexander Gerschenkron

Professor Gerschenkron shows what the study of Russian economic history can contribute to an understanding of the history of western Europe.

Discussing the Old Believers, he casts doubt on the relation of religious views to economic attitudes and forces a review of Weber's thesis on the protestant ethic. Considering the effect of the reforms of Peter the Great on Russian mercantilism, he evokes a new awareness of this throughout Europe, focusing on the bearing of economic backwardness on mercantilism. He ends with a discussion of Russian industrialization during the thirty years preceding World War I.

$\$ 4.95$

\section{THE RISE OF BUSINESS CORPORATIONS IN INDIA 1851-1900}

R. S. RuNGTA

Dr Rungta traces the rise of modern businesses in India by looking at the growth of joint stock companies.

In addition, the book describes the developments in transportation, progress in agriculture, formulation of government policy toward business, establishment of stock exchanges in Bombay and Calcutta, and the effects these factors had on business growth.

$\$ 16.00$

\section{THE UNBOUND PROMETHEUS}

\section{Technological Change and Industrial Development} in Western Europe from 1750 to the Present

\author{
David S. Landes
}

“. . . a scholarly, lively and eminently readable book." - Journal of Economic Literature

Cloth $\$ 8.50$ Paper $\$ 2.95$

\section{CAMBRIDGE UNIVERSITY PRESS}

32 East $57^{\text {th }}$ Street

New York, N.Y. 10022 


\section{THE HISTORY OF AMERICAN MANAGEMENT}

Selections from the

Business History Review

Edited $\&$ with an Introduction by

JAMES P. BAUGHMAN

Harvard Graduate School

of Business Administration

Original essays which view in historical perspective the key problems faced by managers of large-scale American enterprise. The emphasis is on "Big Business" covering the period from 1850 to 1950. Focuses on volatile questions and dramatic incidents in the business world. The essays give substantive information about historical events and provide for discussion of the real world versus the ideal world. Presents sufficient data to provide stimulating discussions about each selection.

(38926-2)

264 pp., cloth $\$ 5.95$

Orders are processed faster if Title and Title Code appear on your order.

For an approval copy, write Box 903

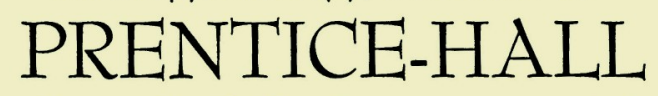

Englewood Cliffs, New Jersey 07632 